\section{Penghilangan dalam Penerjemahan Subtitle Da Vinci's Demons}

Rizky Arif Afandi ${ }^{1}$, Hayatul Cholsy ${ }^{2}$

${ }^{1}$ Mahasiswa Pascasarjana IImu Linguistik UGM

2Dosen Fakultas IImu Budaya UGM

${ }^{1}$ Surel: rizkyarifafandi@gmail.com

\begin{abstract}
INTISARI
Penghilangan dalam penerjemahan subtitle merupakan bagian strategi penerjemahan yang lazim ditemukan. Meskipun telah lazim ditemukan, penghilangan pada penerjemahan, menurut beberapa ahli, masih menimbulkan permasalahan mengenai keutuhan pesan yang disampaikan di dalam teks target dan cenderung dilakukan berdasarkan intuisi penerjemah. Terkait hal ini, pada serial televisi Da Vinci's Demons ditemukan penghilangan dalam frekuensi yang cukup tinggi dan hal inilah yang menjadi tujuan penelitian ini untuk mengkajinya. Penelitian yang bersifat deskriptif komparatif ini menggunakan teori penghilangan Mona Baker mengenai penghilangan, dan meninjau penghilangan dari konten informasinya. Dari hasil penelitian, ditemukan bahwa penghilangan dalam penerjemahan memang tidak bisa dielakkan karena beberapa alasan, yakni; (1) keterbatasan jumlah karakter dalam subtitle; (2) adanya gambar dan suara yang mewakili penghilangan, dan (3) adanya perbedaan budaya.
\end{abstract}

Kata kunci: penghilangan, penerjemahan subtitle, konten informasi

\title{
PENDAHULUAN
}

Berbicara mengenai penerjemahan yang dilihat dari sejarahnya, penerjemahan pada mulanya telah menjadi subjek pembahasan para tokoh ternama dalam bidang akademis, bahkan sejak abad pertama ketika Cicero dan Horace membedakan antara penerjemahan kata demi kata dan makna demi makna (Bassnett, 1980; Munday 2008). Seiiring dengan perkembangannya, dimulai pada pada tahun 1980, kemajuan dalam bidang teknologi yang merubah seluruh alur informasi, kebudayaan, dan hidup masyarakatnya membuat permintaan akan penerjemahan semakin meningkat, sehingga banyaknya hasil terjemahan masa kini menjadikan pengetahuan semakin luas dan batas budaya semakin terbuka.

Hasil dari perkembangan jaman ini, penerjemahan tidak hanya menjadi jembatan antara penutur bahasa asing dan bahasa lokal di suatu tempat dan kebudayaan tertentu melainkan juga mendorong dan memfasilitasi orang asing untuk menerima dan mempelajari bahasa dan kebudayaan yang baru tersebut. Dalam kasus ini, misalnya subtitle dalam berbagai penerjemahan media sekarang, mampu menambah pengetahuan pembaca dan penonton secara umum tentang bahasa asing dan kebudayaannya. Karena dari itu, adalah hal yang penting untuk membahas konsep penerjemahan yang dipakai dalam subtitle yang digunakan dalam penelitian ini. 
Terkait dengan penerjemahan subtitle, di dalam prosesnya tidak terlepas dari tujuannya, seperti yang dikemukakan oleh Samuelsson-Brown (1995: 83), yakni "Untuk siapa terjemahan tersebut dibuat dan bagaimana cara penerjemah menerjemahkannya?". Lantas, pernyataan ini sangat erat terkait dengan proses penerjemahan dalam hal mencapai kesepadanan makna antara teks sumber (TSu) dan teks sasaran (TSa). Demi mencapai kesepadanan ini, Baker (1992) mengemukakan salah satu teknik yang digunakan dalam penerjemahan adalah penghilangan.

Penghilangan satu atau bahkan banyak kata dalam terjemahan adalah hal umum yang dilakukan penerjemah dalam rangka untuk menghilangkan kebingungan di dalam menentukan kesejajaran leksikal dari dua bahasa (Khanmohammad \& Aminzad, 2015). Penghilangan bahkan termasuk salah satu strategi ataupun teknik penerjemahan yang banyak dicanangkan oleh beberapa pakar teori penerjemahan. Sebagai contoh, Baker (1992) mengutarakan bahwa penghilangan merupakan teknik penerjemahan yang lazim ditemui sebagai salah satu solusi mengatasi perbedaan struktur dan leksikal dalam dua bahasa. Struktur dan leksikal yang kompleks yang ditemui oleh penerjemah, umumnya yang terdapat dalam kesastraan atau ditemukannya nilai budaya di dalam teks, dan hal ini, pada kenyataanya, memaksa para penerjemah untuk menghilangkan bagian yang tidak diinginkan dari teks sumber. Beranjak dari ketidak samaan antara dua bahasa baik secara sistemis maupun kebudayannya, secara umum ahli ilmu linguistik setuju bahwa menghilangkan suatu bagian aspek lingual tidak bisa dielakkan. (Baker, 1992; A. Bell, 1991; Bielsa \& Bassnett, 2009; Fairclough, 1995; Newmark, 1988b; Nida, 1969; Venuti, 1998). Begitu juga yang kasusnya yang ditemui ketika teks sumber dari film akan dibuat subtitle dalam bahasa Indonesia. Sebagai pengingat bahwa subtitle adalah jenis teks AVT (Audio Visual Translation) atau penejermahan Audivisual, maka ada perbedaan yang siginifikan antara subtitle dan teks kesastraan pada umumnya seperti novel. Salah satu yang ciri menonjol yang membedakannya adalah keterbatasan jumlah huruf, baris dan ketepatan antara audio dan teks dalam satu bingkai tampilan membuat subtitle unik secara sendirinya. Tentu, subtitle memiliki strategi sendiri dalam menerjemahkannya. Dilansir dari ahli yang telah mendalami penelitian penerjemahan subtitle, Gotlieb (1992), satu dari sepuluh strategi yang dikemukakannya adalah deletion (penghilangan). Akan tetapi timbul pertanyaan, apakah yang dihilangkan tersebut tidak mempengaruhi hilangnya pesan dari teks sumber? Seperti yang dijelaskan Newmark (1998), bertentangan dengan ahli yang telah disebutkan sebelumnya, bahwa penghilangan dalam terjemahan adalah prosedur yang kurang tepat karena mengandalkan intuisi dalam beberapa kasus dan bersifat alternatif (pilihan) dari penerjemah dalam kasus lainnya.

Sejalan dengan ini, hasil dari pengamatan sekilas menunjukkan persamaan pendapat Newmark mengenai penghilangan. Perhatikan contoh berikut ini: 
(a) Episode 5. Menit: 24:04

TSu: your wife, she came by my lab last morning.

TSa: istrimu, dia datang tadi pagi

Omission: my lab

Terlihat dari contoh diatas, ditemukan adanya penghilangan aspek lingual my lab dalam terjemahan bahasa Indonesia, yang menjadi istrimu, dia datang tadipagi, bukan yang seharusnya 'istrimu, dia datang ke laboratoriumku tadi pagi' menimbulkan dugaan bahwa terjemahan ini akan berdampak fatal dalam penyampaian pesan yang kemudian efeknya mungkin mengakibatkan penonton tidak secara utuh mengerti jalan ceritanya meski pada kenyataanya unsur pendukung dalam sebuah tayangan bisa dibantu dengan visual nya. Akan tetapi, tetap timbul keraguan akan ketepatan teknik penghilangan ini.

Contoh lain dibawah ini juga menimbulkan pertanyaan tersendiri.

(b) Episode 2. Time: 18.05

TSu: What on earth happened to you?

TSa: Apa yang terjadi denganmu?

Omission: on earth

Frase on earth pada kenyataanya memang hanya penekanan pembicara akan keterkejutan pada suatu keadaan. Frase ini bersifat informal dan akan sangat sulit untuk diterjemahkan secara harfiah karena tidak ada kaitannya sama sekali maknanya jika dibedah per kata. Untuk bahasa Indonesia sendiri, ungkapan on earth ini mungkin terlalu sulit untuk dicari padanan yang tepat, sehingga kecenderungan penerjemah untuk menerapkan strategi penghilangan ini sangatlah tinggi. Dari contoh ini, beranjak pertanyaan yang mendasar, apakah memang tidak ada padanannya dalam bahasa Indonesia? Atau mungkin keterbatasan jumlah huruf dan baris membuat penerjemah memilih untuk menghilangkannya? Atau dugaan lain adalah ketidakmampuan penerjemah dalam menerjemahkan frase tersebut?

Seperti pemaparan beberapa contoh data di atas, penelitian deskriptif komparatif digunakan dalam penelitian ini, yakni menitik beratkan pada perbandingan dua bahasa berbeda pada TSu dan TSa, yakni bahasa Inggris dan bahasa Indonesia pada subtitle Da Vinci's Demons. Dipilihnya serial televisi Da Vinci's Demons pada penelitian kali ini didasarkan pada beberapa alasan. Pertama, di dalam forum film Palembang Movie Club, sebuah komunitas penggemar film di Palembang, Sumatera Selatan, Da Vinci's Demons sering dibicarakan sebagai salah satu series yang sukar untuk diikuti jalan ceritanya, dan menimbulkan anggapan adanya masalah dalam penyampaian pesan film yang mungkin diakibatkan hasil terjemahan di dalam subtitle bahasa Indonesia. Kedua, sepanjang peneliti menonton banyaknya judul film dan serial televisi, Da 
Vinci's Demons merupakan salah satu serial televisi yang ditemukan banyaknya penghilanganpenghilangan di dalam subtitle bahasa Indonesia. Terakhir, ketersediaan sumber data cukup mudah untuk didapatkan dikarenakan serial televisi ini terkenal di berbagai negara, dengan cakupan distribusi ke lebih dari 130 negara, termasuk Indonesia. Karena banyaknya minat untuk menonton serial televisi ini, maka banyak situs film resmi menyediakan tayangan ini yang dengan mudah untuk didapatkan.

Sejalan dengan tujuan penelitian ini, perlu untuk menekankan apa itu penghilangan yang akan dianalis. Penghilangan ini dimaksudkan sebagai menghilangkan sebuah kata atau banyak kata dalam teks sumber (dialog lisan) kedalam teks target (subtitles bahasa Indonesia). Perlu diperhatikan juga bahwa, penghilangan subtitle juga terkadang bisa terjadi dikarenakan beberapa hal tertentu diluar tataran linguistik, dan ini tidak akan dibahas.

Penghilangan, khususnya dalam subtitle, juga telah dikaji oleh beberapa peneliti sebelumnya dengan teori dan tujuan penelitian yang beragam. Pertama, Kovavic (1998). Fokus penelitiannya adalah melihat penghilangan dari kacamata metafungsi bahasa Halliday. Penelitian kedua dari beberapa penulis yakni Carvalho (2005), Cattrysse (1998), Gambire (2002), dan Gottlieb $(1992,1994)$ berfokus pada alasan penghilangan yang cenderung dilihat dari tataran luar linguistik seperti teknis subtitle dan permintaan klien. Kemudian, Rosa (2001) mengungkapkan alasan penghilangan subtitle yang salah satu fokusnya terkait dengan keadaan sosial politik. Georgapoulou (2013), mengaitkan genre dan konteks dalam penghilangan. Terakhir, penelitian dari Namir dan Soudani (2017) mengungkapkan dua alasan utama penghilangan terkait dengan teknis dan aspek linguistik nya sendiri. Dari penelitian sebelumnya, belum ada yang mengungkit penghilangan ditinjau dari penghilangan yang dicetus Mona Baker - penghilangan konten informasi - yang mana akan menjadi pembeda dari penelitian sebelumnya.

Beranjak dari pemaparan dalam penelitian-penelitian sebelumnya, usaha untuk mengungkap apa saja bentuk penghilangan dan alasan mengapa ada unsur lingual yang tidak diterjemahkan dalam bahasa target (bahasa Indonesia) dalam kasus penghilangan di subtitle sangat penting untuk dikaji. Oleh karena itu, perlu dilaksanakan penelitan lanjutan untuk mengkaji lebih dalam sisi penghilangan dalam subtitle dengan menggunakan salah satu bentuk penghilangan yang dicetus oleh Baker (1992), yakni penghilangan konten informasi. Penelitian ini diharapkan bisa menjadi jalan keluar mengenai konflik secara linguistik dan mungkin perbedaan secara budaya yang terjadi dalam fenomena penghilangan dari teks sumber yang diterjemahkan ke dalam teks target. 


\section{HASIL DAN PEMBAHASAN}

Selama penayangan 5 episode di musim pertama serial TV Da Vinci's Demons, ditemukan 214 penghilangan konten informasi dalam penerjemahan teks sumber (bahasa Inggris) ke teks sasaran (subtitle bahasa Indonesia). Berikut beberapa penjelasan data representatif yang telah dikumpulkan pada penelitian kali ini.

(1) TSu: Then why do you struggle so hard to keep both at bay?

TSa: Lalu mengapa kau berusaha menjauhinya?

(episode 1, menit ke: 01.25)

Di dalam penerjemahan TSu ke TSa, salah satu frasa yang terjadi penghilangan dalam penerjemahan adalah frasa adjectiva yang terdiri dari adverbia kualitas so dan adjektiva hard yang keduanya bisa diartikan sangat gigih. Frasa adjektiva ini dipilih untuk diterjemahkan, dan penerjemah hanya menerjemahkannya menjadi 'lalu mengapa kau berusaha menjauhinya?', yang seharusnya hasil terjemahan bisa menjadi 'lalu mengapa kau sangat berusaha menjauhinya'? Penekanan keterangan kualitas yang menggambarkan to keep both at baymenjauhi ditiadakan dalam hasil terjemahan. Penekanan akan kualitas seberapa besar usaha untuk menjauhi dalam TSu tampaknya tidak memiliki siginifikansi dalam penyampaian pesan cerita, sehingga tidak ditampilkan juga dalam hasil terjemahan. Kemungkinan alasan lain yakni adverbia jenis kualitas ini dianggap tidak terlalu berpengaruh dalam alur cerita sehingga penonton dianggap akan tetap memahami jalan cerita. Hal ini senada dengan Baker (1992) yang menjelaskan bahwa beberapa aspek lingual bisa dihilangkan asalkan pesan inti tetap hadir di dalam hasil terjemahan. Oleh karena itu, hasil terjemahan dianggap tetap sepadan secara maknanya, karena tidak berdampak pada hilangnya pesan yang ingin disampaikan.

(2) TSu: You see? Those weighted ribbons

TSa: Kau lihat? Pita-pita itu

(episode 1, menit ke: 06.42)

Bebeda kasusnya dimana adverbia dihilangkan dalam penerjemahan, data diatas menunjukkan bahwa penghilangan adjektiva juga terjadi. Di dalam TSu, weighted dalam frasa weighted ribbons tidak diterjemahkan. Jika diterjemahkan secara utuh pada TSa, hasil terjemahan seharusnya akan menjadi pita-pita berat itu, tetapi ditemukan hasilnya hanya menjadi pita-pita itu. Tentu secara penyampaian pesan, hasil terjemehan ini dianggap tidak maksimal. Frasa weighted ribbons menggambarkan bahwa pita tersebut memiliki karakteristik berat yang mungkin akan membedakan dengan bentuk-bentuk pita lainnya. Di dalam hasil terjemahan, jika hanya diterjemahkan menjadi pita, tentu secara utuh tidak memberikan gambaran lengkap mengenai pita. Yang menjadi menarik adalah kemungkinan alasan mengapa terjadinya penghilangan dalam adjektiva ini. Alasan terbatasnya jumlah karakter dalam sifat subtitle tampaknya tidak 
dibenarkan karena jumlah karakter masih memungkinkan untuk menambahkan kata sifat berat berdampingan dengan pita tersebut.

Jika secara jumlah karakter di dalam subtitle bukan menjadi alasan, maka kemungkinan alasan lain mengapa penerjemah menghilangkan adjektiva weighted dikarenakan adanya tampilan visual yang mendukung penjelasan penutur. Ketika penutur mengucapkan frasa weighted ribbons, terlihat gambar pita secara jelas dalam tayangan. Subtitle memang tidak bisa dilepaskan dari peran visual (gambar) sebagai pelengkap penyampaian pesan. Meskipun demikian, alasan ini hanya menjadi dugaan dikarenakan tidak akan dikaji lebih mendalam multimodal linguistik, yakni seperti gambar-gambar ataupun suara yang melingkupi subtitle karena penelitian ini hanya mengkaji apa yang ada di dalam komponen teks subtitle.

(3) TSu: We're not fucking peacocks, Giuliano.

TSa: Kita bukan burung merak, Giuliano.

(episode 1, menit ke: 11.19)

Penghilangan intensifier yang berupa kata vulgar, seperti salah satunya fucking sangat sering ditemukan. Sebagai contoh, pada data (3), bahwa intensifier (kata penekanan) yang bersifat kasar dipilih untuk tidak diterjemahkan. Di dalam TSu, kalimat we're not fucking peacocks, Guliano diterjemahkan menjadi kita bukan burung merak, Giuliano, yang bisa saja hasil terjemahannya menjadi kita bukan burung merak sialan, Giuliano. Kata fucking dipilih untuk diterjemahkan dan hal ini mungkin dilandasi oleh beberapa hal. Pertama, penerjemah mungkin menganggap kata fucking terlalu vulgar, tidak senonoh untuk diterjemahkan. Berdasarkan kamus Oxford, fucking pada faktanya tergolong pada vulgar slang, dan pada salah satu tataran fungsinya, kata fucking digunakan untuk menunjukkan kemarahan. Kedua, meskipun dihilangkan, kata fucking tidak terlalu mempengaruhi isi pesan yang disampaikan. Kembali lagi bahwa tujuan penerjemahan adalah menyampaikan pesan semaksimal mungkin, maka penerjemah mungkin memilih tidak menerjemahkan intensifier karena tidak mempengaruhi pesan inti dalam TSu. Alasan ketiga mengenai kebudayaan dan peraturan sensor yang ada di Indonesia. Di dalam TSa, bahasa Indonesia tidak selalu dibubuhi kata intensifier seperti ini, terlebih lagi jika dalam tataran budayanya, fucking dianggap sebagai kata kasar, sehingga lembaga sensor Indonesia memutuskan untuk menghilangkan bagian suara (soundtrack) yang mengandung kata-kata kasar, salah satunya adalah fucking. Dari beberapa alasan penghilangan ini, bisa dikatakan bahwa hasil terjemahan tetap sepadan, mengingat pesan tetap tersampaikan. Akan tetapi, hasil terjemahan tidak sepenuhnya menggambarkan keadaan seberapa besar penutur merasakan kemarahannya dan hasil terjemahan pada data diatas cenderung menjadi lebih formal. Terdapat dilema yang mungkin dirasakan oleh penerjemah untuk menerjemahkan kata vulgar ini. Penerjemah tentu mempertimbangkan regulasi lembaga sensor Indonesia dan 
kebudayaan penonton Indonesia itu sendiri untuk tidak menerjemahkan kata vulgar seperti itu meskipun secara emosi di dalam pesan TSu tidak sepenuhnya tersampaikan.

(4) TSu: just pay the degenerate and be done with it.

TSa: bayar dia dan tuntaskan semua urusannya

(episode 1, menit ke: 17.19)

Penghilangan nomina persona yang dianggap spesifik pun ditemukan, seperti pada data (4). Kata the generate yang di dalam kamus Oxford berarti koruptor (orang yang korupsi) tidak diterjemahkan ke TSa dan hasil terjemahannya hanya menjadi bayar dia. Kata dia di dalam TSa yang menunjukkan seseorang, tampaknya tidak cukup mewakili karakteristik seseorang yang melakukan tindakan korupsi. Makna dia terlalu luas dan secara pesan pun tidak tersampaikan dengan baik. Hasil terjemahan ini dianggap tidak sepadan secara leksikal. Jika merujuk pada jumlah karakter dan waktu di dalam subtitle, penerjemah sebenarnya masih bisa menerjemahkan secara maksimal menjadi bayar si koruptor itu dan tuntaskan semua urusannya, karena jumlah karakter tidak melebihi dan secara waktu juga lebih dari durasinya. Tidak banyak ditemukan kasus seperti ini pada data yang dikumpulkan, dan satu-satunya alasan terjadinya penghilangan ini adalah adanya anggapan bahwa penonton sudah memahami pesan dari bantuan visual yang tersaji, karena ketika kalimat dalam TSu diatas diucapkan, pemeran menunjuk langsung sang koruptor tersebut dan muncullah gambaran lengkap si koruptor tersebut.

(5) TSu: - The priests in Egypt understood that.

- We are not in Egypt.

TSa: $\quad$ - Pendeta-pendeta di Mesir...

- Kita tidak sedang di Mesir.

(episode 1, menit ke: 20.25)

Fenomena penghilangan lain terjadi pada contoh data diatas. Frasa verba understood that tidak diterjemahkan ke TSa. Dalam kalimat The priests in Egypt understood that diterjemahkan menjadi pendeta-pendeta di Mesir... Understood that yang menurut kamus Oxford berarti memahami itu tidak ada dalam hasil terjemahan. Tidak terlalu jelas alasan mengapa penghilangan ini terjadi dan jika dikaitkan faktor terbatasnya karakter dan waktu, kedua hal ini tidak menghalangi hadirnya frasa verba ini dalam TSa. Terlebih lagi jika lihat dari sisi sintaksisnya, kalimat dalam TSa belum lengkap jika verba tidak hadir. Dalam kasus ini, pesan dalam TSu tentu tidak tersampaikan sehingga bisa dikatakan bahwa hasil terjemahan tidak sepadan. 
(6) TSu: - A fortress?

- A fortress that had been breached.

TSa: - Benteng?

- Yang sudah dibobol.

(episode 1, menit ke 53.54)

Penghilangan juga terjadi terkait dengan informasi lama. Pengulangan tampaknya diabaikan untuk dihadirkan kembali ke hasil terjemahan. Pada data (6) frasa nomina a fortress yang dalam bahasa Indonesianya diartikan menjadi benteng tidak diterjemahkan dibaris kedua. Jika dilihat dari baris pertama, a fortress telah diterjemahkan secara maksimal di dalam TSa, sehingga ini dianggap sebagai informasi lama dan penerjemah menganggap tidak akan mempengaruhi pesan dari TSu. Sejalan dengan temuan ini, Georgakopolou (2003) juga berpendapat bahwa penghilangan dapat dilakukan dalam hal pengulangan kata yang telah jelas di dalam suatu konteks tertentu. Dia juga menambahkan bahwa Audio juga mendukung penonton untuk tahu apa yang dimaksud dari teks sumber. Dari analisa ini, dapat diketahui bahwa hasil terjemahan tetap dikatakan sepadan secara makna karena pesan dalam TSu tetap tersampaikan secara utuh.

(7) TSu: How the devil did you do it?

TSa: Bagaimana bisa kau melakukannya?

(episode 1, menit ke: 47.20)

Kemudian, kata yang tergolong interjeksi seperti pada data (7) juga dihilangkan. Frasa the devil dari kalimat tanya how the devil did you do it? tidak diterjemahkan dan hasil terjemahannya hanya menjadi Bagaimana bisa kau melakukannya?. Jika kita berbicara akan budaya bahasa TSu, interjeksi seperti, the devil, memang banyak sekali digunakan. Dalam penggunaan bahasa Inggris, kecenderungan penggunaan interjeksi yang bersifat non-formal ini menggambarkan emosi penutur bahwa si penutur sedang dalam keadaan kesal. Banyak sekali di dalam data yang dikumpulkan ditemui penghilangan interjeksi dalam praktik penerjemahan. Kemungkinan alasan utamanya adalah perbedaan budaya antara TSu (bahasa Inggris) dan TSa (bahasa Indonesia). Penutur bahasa Indonesia tidak sesering penutur bahasa Inggris menggunakan interjeksi dalam jenis kalimat apapun, termasuk kalimat tanya seperti data (7). Terlebih lagi jika melihat dari makna kata devil berdasarkan kamus Oxford yang berarti roh jahat atau setan, tampaknya terlalu kasar untuk diterjemahkan ke bahasa Indonesia. Penerjemah lebih memilih menghilangkannya dan tetap menyampaikan makna inti dari TSu tanpa disertai interjeksi. Untuk masalah kesepadanan, meskipun dihilangkan, secara kesepadanan leksikal, hasil terjemahan tetap dikatakan sepadan meski secara emosi penutur tidak tergambarkan di dalam subtitle. 
(8) TSu: Apparently, they caught him breaking into the bookshop on the Via dei Librai.

TSa: Mereka menangkap ia sedang mengendap ke sebuah toko buku di Via Dei Librai. (episode 2, menit ke 28.55)

Data selanjutnya menunjukkan penghilangan dalam kata penghubung (linking words). Adverbia apparently di dalam data (8) tidak diterjemahkan ke TSa. Apprentely berdasarkan kamus Oxford tergolong pada kata penghubung yang fungsinya menghubungkan kalimat dengan kalimat sebelumnya. Kata ini bermakna tampaknya dan dominan muncul di awal kalimat. Pada TSa, kata ini tidak diterjemahkan. Meskipun demikian, pesan dari TSu ke TSa yang terlihat pada data (8) tetap tersampaikan secara maksimal. Penghilangan ini terjadi dikarenakan kemungkinan terbatasnya jumlah karakter dalam satu bingkai layar. Jika apparently diterjemahkan menjadi tampaknya, mereka menangkap ia sedang mengendap ke sebuah toko buku di Via Dei Librai, maka jumlah karakter akan sangat panjang dan tidak akan cocok dengan durasi audio di layar. Sejalan dengan ini, menurut penelitian Kovavic (1998), kata hubung dalam kategori fungsi tekstual, memang kerap terjadi penghilangan karena dianggap tidak terlalu mempengaruhi isi pesan yang akan disampaikan. Kesepadan tetap tercapai meskipun terjadi penghilangan kata hubung apparently.

(9) TSu: - Get the horses.

- Hurry, hurry.

TT: $\quad$ - Cepat!

(episode 2, menit ke: 02.27)

Kalimat perintah juga ditemukan hilang dalam hasil terjemahan pada data (9). Kalimat perintah get the horses tidak diterjemahkan sama sekali dalam bahasa sasaran. Di dalam teks sasaran, hanya terdapat ajakan untuk cepat tanpa menunjukkan kalimat get the horses yang jika diartikan menurut kamus Oxford, berarti siapkan kudanya. Jika berbicara mengenai kesepadanan, tentu ini dikatakan tidak sepadan karena pentingnya kalimat perintah tersebut tentang apa yang akan disiapkan. Akan tetapi, jika menelisik dari sudut pandang visualnya, gambaran kuda memang ditunjukkan di dalam layar. Hal ini kemudian menimbulkan dugaan bahwa penerjemah memilih untuk tidak menerjemahkan kalimat perintah tersebut dikarenakan telah diwakili dengan visual kuda-kuda yang disajikan. Kasus penghilangan total ini terjadi dalam kuantitas yang cukup banyak, tercatat ada 28 data yang memiliki kasus yang sama, yang kesemuanya jika dianalisa diakibatkan oleh kemungkinan adanya bantuan visual (gambar-gambar) untuk menyampaikan pesan.

(10)TSu: Not to worry, they can only have our entrails torn out with rusty sucket forks.

TT: Jangan khawatir. Mereka cuma bisa mencabik isi perut kita keluar.

(episode 2, menit ke: 21.28) 
Ketidaksepadanan dalam penerjemahan juga terjadi pada data (10). Frasa with rusty sucket forks dalam kalimat Not to worry, they can only have our entrails torn out tidak diterjemahan dan hanya menjadi jangan khawatir, mereka cuma bisa mencabik isi perut kita keluar". Jika dilihat dari kamus Oxford, rusty sucket forks memiliki arti garpu-garpu berkarat, yang mana ini tidak terlihat dari hasil terjemahan di TSa. Tentu, hasil terjemahan ini tidak sepadan dikarenanakan tidak ada informasi penting yang mengungkapkan dengan alat apa digunakan untuk mencabik isi perut mereka. Dari segi budaya, di Indonesia sendiri, frasa garpu-garpu berkarat tidak dikenal sebagai alat untuk mencabik atau bahkan tindakan terlarang lainnya. Garpu umumnya digunakan sebagai alat makan. Sejalan dengan alasan kebudayaan ini, Baker (1992) mengemukakan bahwa penghilangan dapat menjadi jawaban untuk membatasi perbedaan budaya yang akan menyebabkan kebingungan para pembaca. Dengan alasan inilah, kemungkinan penerjemah mengabaikan alat tersebut untuk diterjemahkan sebagai media pencabik perut. Alasan kedua adalah keterbatasan karakter dan waktu. Jika keseluruhan frasa diterjemahkan dan akan menjadi Jangan khawatir. Mereka Cuma bisa mencabik isi perut kita keluar dengan garpu-garpu berkarat, maka jumlah karakter melebihi batas subtitle dalam satu bingkai layar.

(11) TSu: and then entered the Via dei Librai here.

TSa: dan masuk ke jalan tepat di sini.

(episode 2, menit ke: 28.55)

Dari data (11), di dalam TSu, frasa the Via dei Librai merupakan frasa berbahasa Italia. Jika secara harfiah diartikan penjual buku jalanan, maka di dalam TSa, ada ketidak hadiran makna ini secara eksplisit. Hasil terjemahan dalam TSa hanya menyebutkan dan masuk ke jalan tepat disini. Penerjemah seharusnya bisa mencantumkan secara spesifik jalanan apa yang dimaksud tanpa menghilangkan the Via dei Librai. Akan tetapi, dalam kebudayaan di Indonesia, buku-buku pada umumnya biasanya dijual dalam suatu toko buku khusus dan jarang untuk dijual dipinggirpinggir jalan. Perbedaan budaya antara TSa dan TSu inilah yang mungkin menyebabkan penerjemah tidak memasukkan secara spesifik tentang jalan apa yang dimaksud. Meskipun secara kesepadanan tidak tercapai, jika dilihat dari tampilan visual yang ada, penonton bisa menangkap apa yang dimaksud dengan jalan tersebut karena telah dibantu dengan gambaran jelas yang ada di layar.

(12) TSu: Stay down, asshole.

TSa: ---

(episode 5, menit ke: 05.57)

Ketidaksepadanan juga ditemukan dalam data (12). Tidak diterjemahkannya stay down, asshole, mengakibatkan TSa tidak memiliki bentuk apapun, dalam hal ini kosong. Jika dilihat dari kamus Oxford, stay down berarti diam ditempat dan asshole yang termasuk kata vulgar, bisa dimaknai 
keparat dan terkategori dalam slang. Tidak ada alasan pasti mengenai penghilangan total ini. Penerjemah mungkin beranggapan bahwa ketidak sopanan kata asshole yang juga secara sensor harus dihilangkan dan adanya soundtrack dan gambar yang menggambarkan untuk diam ditempat dianggap cukup mewakili untuk menyampaikan pesan ke penonton. Tanpa ada satu katapun di dalam TSa, penonton dianggap mampu melihat runtutan kejadian melalui gambar dan suara.

Berdasarkan contoh data diatas, dapat dikatakan bahwa penghilangan konten informasi dalam penerjemahan subtitle Da Vinci's Demons ke subtitle bahasa Indonesia secara dominan terjadi pada tataran penghilangan kata, frasa, atau klausa yang tidak terlalu penting dalam penyampaian pesan. Penghilangan tersebut juga dominannya bisa diwakili melalui gambar ataupun suara untuk penyampaian jalan ceritanya ke penonton. Akan tetapi, muncul pertimbangan-pertimbangan tertentu mengapa penghilangan dalam penerjemahan subtitle ini terjadi. Seperti yang telah didapatkan melalui beberapa data yang disajikan sebelumnya, penghilangan dapat terjadi dengan mempertimbangkan:

1) Adanya batas karakter dan waktu dalam satu layar. Subtitle memiliki keunikan tersendiri dibandingkan dengan jenis teks lainnya. Jika karakter telah melebihi batas yang ditentukan dan sinkronisasi waktu juga sudah tidak tepat, maka penghilangan sangat bisa terjadi. Terbukti dengan dugaan hasil pada data (..) yang menunjukkan bahwa jika diterjemahkan secara utuh maka jumlah karakter akan melebihi batas yang ditentukan.

2) Gambar dan audio (suara) bisa mewakili pesan yang ingin disampaikan. Tidak jarang terjadi, informasi penting dalam TSu tidak diterjemahkan ke TSa. Hal ini sangat berkaitan dengan tampilnya gambar yang bisa mewakili pesan yang seharusnya diterjemahkan. Penerjemah menganggap dengan melihat gambar tanpa disertai teks, penonton sudah memahami jalan cerita dari tayangan. Tidak bisa dielakkan bahwa subtitle sangat terkait dengan sinkronisasi gambar dan suara. Berbeda seperti teks dalam novel yang hanya berupa teks di dalam sebuah lembaran, subtitle hadir dalam suatu tayangan yang disertai gambar dan suara. Meskipun tidak dikaji multi-modal linguistik yang salah satunya mencakup gambar dan suara, peran visual-audio tetap tidak bisa dihindarkan dari alasan-alasan penghilangan dalam penerjemahan.

3) Perbedaan budaya antara TSu dan TSa. Perbedaan budaya ini diwakili dengan beberapa kata vulgar yang muncul dalam TSu. Penerjemah memilih untuk menghilangkannya karena terkait dengan ketidak cocokan budaya antara budaya barat dan Indonesia. Meskipun dianggap wajar menggunakan kata-kata vulgar dalam mengekspresikan kemarahan di dalam bahasa Inggris, ini berbeda dengan yang terjadi pada penutur bahasa Indonesia. 
Penggunaan kata vulgar masih dianggap 'tabu' bagi sebagian besar penutur bahasa Indonesia terlebih lagi jika kita melihat mayoritas penduduk Indonesia adalah Muslim. Bahkan, regulasi sensor di Indonesiapun mengharuskan jenis kata ini untuk dihilangkan bahkan ditiadakan - tidak diperdengarkan. Perbedaan budaya ini juga menjadi faktor yang tak bisa dihindari oleh penerjemah. Dari data yang ada, meskipun perbedaan budaya mengakibatkan penghilangan, sebagian besar penghilangan terjadi karena budaya ini tidak mempengaruhi isi pesan inti yang ingin disampaikan.

\section{KESIMPULAN}

Dari analisis penghilangan subtitle berdasarkan teori Mona Baker, didapatkan bahwa penghilangan terbanyak terdapat pada konten informasi yang dianggap tidak memiliki signifikansi dalam penyampaian pesan. Kemudian, penghilangan paling sedikit dijumpai pada satu kalimat utuh yang terdapat informasi penting. Hal ini bisa diprediksi dari penelitianpenelitian sebelumnya bahwa konten informasi yang tidak terlalu penting dalam penyampaian pesan mengalami penghilangan paling banyak karena terkait dengan keekonomisan bahasa dalam TSa. Dari analisis ini kemudian ditemukan bahwa alasan utama penghilangan ini terkait tiga hal, yakni karena keterbatasan jumlah karakter dan waktu, adanya gambar dan audio yang mewakili jalan cerita dan perbedaan budaya. Secara garis besarnya, tidak ditemukan penyimpangan penyampaian pesan film ke penonton ketika satu atau dua elemen linguistik dihilangkan. Meskipun secara semiotik diluar teks tidak diteliti, pengaruhnya dalam pemahaman penonton tetap saja tidak bisa dihindari. Akhirnya secara keseluruhan bisa disimpulkan bahwa penghilangan yang diungkap melalui bentuk penghilangan yang dicetus Baker pada dasarnya bisa diterima dan tidak mempengaruhi pesan film sehingga bisa dikatakan juga bahwa timbulnya kesulitan penonton dalam mencerna isi film mungkin disebabkan hal lain seperti alur yang acak, dan bukan karena terjemahan subtitle itu sendiri.

\section{DAFTAR PUSTAKA}

Baker, M. (1992). In Other Words: A Coursebook on Translation. London: Routledge.

Bassnett, S. (1980). Translation Studies. London: Methuen.

Bell, R. T. (1991). Translation and Translating: Theory and Practice. New York: Longman.

Bielsa, E., \& Bassnett, S. (2009). Translation in Global News. New York: Routledge.

Carvalho, C. A. (2005). A tradução para legendas: dos polissistemas à singularidade do tradutor. 2005. Disertation (Mestrado em Letras). Pontifícia Universidade Católica do Rio de Janeiro.

Cattrysse, P. (1998) Translation in the new media age. Painosalama Ou, Turku: Centre for Translation and Interpreting. 
Fairclough, N. (1995). Media Discourse. London: Arnold.

Gambier, Y. (1994). Audio-Visual Communication: Typological Detour. In C. Dollerup, A.

Georgakopoulou, P. (2003). Reduction levels in subtitling: DVD subtitling: a compromise of trends. Unpublished PhD thesis, University of Surrey, Guildford.

Gottlieb, H. (1992). Subtitling - A New University Discipline. In C. Dollerup \& A.

Loddegaard (Eds.), Teaching Translation and Interpreting: Training, Talent and Experience (pp. 161-170). Amsterdam: John Benjamins.

Gottlieb, H. (1997). Subtitles, Translation and Idioms. Copenhagen: University of Copenhagen.

Gottlieb, H. (1998). "Subtitling", in Baker, Mona (ed), Routledge Encyclopedia of Translation Studies. London: Routledge, 244-248.

Hatim, B., \& Munday, J. (2004). Translation: An Advanced Resource Book. New York: Routledge.

Khanmohammad, H. \& Aminzad, A. A Study of Additions and Omissions in English Translations of Persian-based Social (p.7-27). Islamic Azard University

Kovačič, I. (1994). Relevance as a Factor in Subtitling Reductions. In C. Dollerup, A. Lindegaard, Teaching Translation and Interpreting (pp. 245-251). Amsterdam: John Benjamins.

Kovačič, I. (1998). Six Subtitlers-Six Subtitling Texts. In L. Bowker, M. Cronin, D.

Munday, J. (2008). Introducing Translation Studies: Theories and Applications. London: Routledge.

Namir, H., \& Soudani, N. (2017). The effects of Omission in Audiovisual Translation: Case Study: "Dr. House" Season 2\&3. Thesis: Kasdi Merbah Ouargla University

Newmark, P. (1988b). A Textbook of Translation. London: Prentice Hall International.

Nida, E. A. (1969). Toward a Science of Translating. Leiden: E. J. Brill.

Rosa, A. (2001). Features of Oral and Written Communication in Subtitling. In Y.

Gambier \& H. Gottlieb (Eds.), (Multi)Media Translation: Concepts, Practice, and Research (pp. 213221). Amsterdam: John Benjamins.

Samuelsson-Brown, G. (1995). A Practical Guide for Translators. Clevedon: Multilingual Matters.

Venuti, L. (1998). The Scandals of Translation: Towards an Ethics of Difference. London: Routledge. 